\title{
Antoni Mironowicz, Marcin Mironowicz, Św. Antoni Supra- ski, Białystok 2014, Wyd. Orthdruk, ss. 44
}

Jeszcze kilka lat temu nikt nie wiedział o św. Antonim Supraskim. Opracowana przez Antoniego Mironowicza i Marcina Mironowicza biografia Świętego zasługuje na szczególną uwagę. Podstawowym źródłem poznania życia i męczeństwa św. Antoniego Supraskiego stał się dla autorów monografii żywot świętego, który został wstawiony do rękopiśmiennego wierszowanego Prołogu na miesiące wrzesień-luty. Znajdujący się na początku XVI wieku w monasterze supraskim Prołog został napisany ok. 1496 roku. Został on wykonany na zamówienie „Sołtana Sołtanowicza, namiestnika bielskiego”. Namiestnikiem bielskim (1492-1494) był marszałek hospodarski (1482-1493), namiestnik słonimski (1482-1490) i nowogródzki (1486-1487) Sołtan Aleksandrowicz, syn podskarbiego królewskiego Aleksandra Jurewicza.

Wrześniowo-lutowy Prołog wierszowany, który obecnie znajduje się w kolekcji Aleksego S. Uvarova Państwowego Muzeum Historycznego w Moskwie, składa się z żywotów świętych od września do lutego. Teksty żywotów zostały spisane w latach osiemdziesiątych XV wieku, a żywot św. Antoniego Supraskiego został wstawiony do rękopisu na k. 478-479 w latach 1540-1541.

W ostatnim czasie ukazały się trzy krótkie monografie poświęcone św. Antoniemu Supraskiemu autorstwa: Anatola Turiłowa, Antoniosa Tachiaosa, Antoniego i Marcina Mironowiczów. Praca tych ostatnich autorów jest najbardziej kompetentna, wszechstronna i zawiera najnowsze ustalenia odnośnie dziejów monasteru supraskiego i św. Antoniego.

Żywot św. Antoniego Supraskiego spisano w jednym z klasztorów athoskich na podstawie opowieści mnichów. Żywot ten był znany mnichom supraskim, ponieważ wielu zakonników ze Świętej Góry Athos przebywało w prawosławnych ośrodkach monastycznych na terenie Wielkiego Księstwa Litewskiego. Dodanie do XV-wiecznego Prołogu żywotu św. Antoniego Supraskiego wskazuje na to, że postać męczennika wśród mnichów budziła powszechny szacunek. Świętego supraskiego dołączono do grona świętych z poprzednich stuleci, którzy w swych krajach obdarzeni byli powszechnym kultem. 
Według autorów, język tekstu żywotu św. Antoniego wskazuje na to, że został on napisany przez mnicha $\mathrm{z}$ ziem ruskich, który nie posiadał dobrego kunsztu literackiego. Autor dodatku do Kodeksu znajdował się pod wpływem piśmiennictwa bułgarskiego. W literaturze naukowej dominuje przekonanie, że pochodzący prawdopodobnie z Wołynia bądź Podlasia autor żywotu św. Antoniego Supraskiego albo przebywał na Świętej Górze Athos w bułgarskim monasterze ochrydzkim, albo oparł się na starszej bułgarskiej wersji zapisu hagiograficznego, która trafiła na ziemie ruskie. Występowanie rękopisów bułgarskich na terenie Wielkiego Księstwa Litewskiego w XV i XVI stuleciu było zjawiskiem dość częstym. Niestety, nie posiadamy żadnego dowodu na istnienie wcześniejszego bułgarskiego oryginału żywotu świętego męczennika supraskiego. W tej sytuacji należy przyjąć, że jego anonimowy autor - Rusin sam przebywał w monasterze na Górze Athos, gdzie znajdowały się księgi napisane w języku bułgarskim i tam poznał losy Antoniego Supraskiego.

Według Antoniego Mironowicza twórcą żywotu św. Antoniego był mnich supraski Arseniusz, który trafił do monasteru serbskiego w Chilandarze po 1536 roku. W 1530 roku mnich supraski Arseniusz, były duchowny Aleksy, skopiował pracę św. Jana Klimaka Лествица. Книга Лествица в полдесть, która znajdowała się w monasterze przed 1530 rokiem. W wyniku powstałego konfliktu z archimandrytą Sergiuszem Kimbarem, hieromnich Arseniusz zabrał skopiowaną przez siebie pracę św. Jana Klimaka Лествииa i udał się do serbskiego monasteru Chilandar na Świętej Górze Athos. Arseniusz, słysząc o męczeństwie schimnika Antoniego mógł uwiecznić jego żywot i odesłać do monasteru supraskiego. I choć teza ta nie ma potwierdzenia źródłowego, znajduje swoje uzasadnienie we wspólnym pochodzeniu obu mnichów, pobycie w tym samym serbskim klasztorze na Athosie oraz następstwie czasowym. Arseniusz trafił do Chilandaru w drugiej połowie lat trzydziestych XVI wieku, a żywot św. Antoniego powstał przed 1540 rokiem i został dołączony do supraskiego Prołog $u$ w roku następnym.

$\mathrm{W}$ pracy znajdujemy dokładny opis żywotu i męczeństwa św. Antoniego Supraskiego, który prawdopodobnie pochodził z Bielska. Z przeanalizowanego tekstu żywotu męczennika autorzy wysnuli wniosek, że Onufry (imię przed przyjęciem ślubów zakonnych) nie zawsze żył pobożnie. Znany był z nadmiernej pobudliwości, co doprowadziło go do zabójstwa człowieka. Wkrótce obudziły się w nim normy chrześcijańskiej moralności i poczucie głębokiej winy. Stan taki doprowadził Onufrego do szczerej modlitwy, przemyślenia swego świeckiego życia, skruchy i chęci odbycia pokuty. Dążenie do oczyszczenia duszy i chęć naprawienia winy spowodowały, że młody Podlasianin zdecydował się odbywać pokutę przez resztę swego życia. Młodzieniec został przyjęty do monasteru Zwiastowania Najświętszej Maryi Panny. Z przytoczonego fragmentu wynika, że wstąpił on do jeszcze budującego się nad rzeką Supraśl monasteru.

Wzmianka ta pozwoliła wybitnemu znawcy dziejów klasztoru supraskiego Antoniemu Mironowiczowi na ustalenie roku przybycia Onufrego do monasteru. 
Według tego badacza nastąpiło to po przeniesieniu monasteru z Gródka na uroczysko Suchy Hrud nad rzeką Supraśl. Przybycie Onufrego do budującego się monasteru datuje się po 1508 roku. Opiekę duchową nad nim przejął znajomy mu lub jego rodzicom ihumen Pafnucy Sieheń.

Onufry, pragnąc odpokutować swe grzechy, powziął zamiar udania się do krajów „agarańskich”, by umrzeć tam za Chrystusa. Mianem kraju agarańskiego określano wówczas Turcję i kraje bałkańskie okupowane przez Imperium Osmańskie. Onufry uznał, że najpełniej oczyści się ze swojego grzechu, jeżeli umrze za wiarę. Onufry prosił ihumena Pafnucego, aby mógł udać się na Świętą Górę Athos, by tam porozmawiać na temat swojego zamysłu z pobożnymi mnichami. Pafnucy Sieheń uświadomił sobie, że trudno będzie zatrzymać młodego i gorliwego mnicha, więc przyjął inne rozwiązanie. W tajemnicy przed ogółem braci zakonnej zaprosił kilku starszych mnichów i podstrzygł Onufrego w wielką schimę, nadając mu imię Antoni. Równocześnie ihumen dał Antoniemu zgodę na wyjazd na Świętą Górę Athos. Mnich Antoni miał towarzyszyć zakonnikom z Athosu, którzy po pobycie w monasterze supraskim wracali do swych monasterów.

Po przybyciu na Górę Athos mnich Antoni przedstawił mieszkającym tam ojcom zakonnym swój zamiar oddania życia za Chrystusa. Mnisi athoscy, podobnie jak uprzednio uczynił ihumen Pafnucy, odradzali mu taki rodzaj pokuty. Według nich sam Bóg wezwie go do męczeństwa i dania świadectwa swej wiary, jeżeli przyjdzie odpowiednia chwila. Następnie ojcowie poradzili Antoniemu, ażeby zamieszkał w wieży św. Sawy Serbskiego. Po kilku latach pobytu Antoniego na Athosie do kielii św. Sawy dotarły informacje o męczeństwie Jana, który pochodził, według świętego biografa, z serbskiego miasteczka w prowincji macedońskiej okupowanej przez Turków.

Według Anatola Turiłowa św. Antoni przybył na Świętą Górę Athos przed 1507 rokiem, a jego śmierć nastąpiła 17 lutego 1508 roku. Antoni Mironowicz, nie rozstrzygając ostatecznie o dacie męczeństwa św. Antoniego Supraskiego, zwrócił uwagę na fakt, że monaster supraski na nowym miejscu zaczął funkcjonować dopiero od 1507 roku, a mnich Onufry wstąpił do niego, kiedy obiekt był w budowie. $\mathrm{Z}$ tego powodu opuszczenie monasteru supraskiego przez schimnika Antoniego, jego podróż do Świętej Góry Athos, pobyt w celi św. Sawy Serbskiego musiały mu zająć co najmniej dwa lub trzy lata. Ustalenia A. Turiłowa nie zmieniają faktu, że Antoni Supraski podjął swoją decyzję o męczeństwie na wieść o śmierci innej postaci po 1510 roku. Mnich Antoni pozostawił kielię, opuścił Świętą Górę Athos i udał się do Salonik, do jednej z najstarszych cerkwi Acheiropoietos z V wieku. Cerkiew ta została zajęta przez Turków i w 1430 roku przerobiona przez sułtana Murata II (1421-1451) na meczet.

Po przybyciu do Salonik schimnik Antoni wszedł do cerkwi Bogurodzicy Acheiropoietos w czasie, kiedy Turcy sprawowali muzułmańskie obrzędy. Prawdopodobnie był to piątek, ponieważ w tym dniu muzułmanie zbierali się na nabożeństwa. W czasie muzułmańskiego nabożeństwa Antoni Supraski zaczął 
się modlić, wykonał znak krzyża i stanął na kolanach. Taką postawę mnicha muzułmanie uznali za obrazę ich religii, schwytali Antoniego i poddali torturom. Zakonnik został zamknięty w więzieniu, pozbawiony pożywienia i picia. Turcy ponownie chcieli zmusić Antoniego do wyrzeczenia się wiary chrześcijańskiej. Ten nie tylko tego nie uczynił, ale swymi gestami pokazał paszy i sędziemu, że pójdą do wiecznego ognia. W reakcji na gesty supraskiego zakonnika sędzia polecił spalić ciało mnicha, a popiół rozrzucić w powietrzu. W ten sposób Turcy chcieli uniknąc sytuacji, w której ciało Antoniego mogło się stać obiektem kultu wśród chrześcijan. Dokładna data męczeństwa św. Antoniego i jego śmierci według kalendarza juliańskiego przypada na 4 (14) lutego 1516 roku.

Opracowanie biografii męczennika zostało zakończone oryginalnym tekstem żywotu św. Antoniego Supraskiego, który pozwala kolejnym badaczom na własne analizy i ustalenia. Do żywotu dołączono kondakt i tropar, czyli specjalne modlitwy ku czci świętego męczennika. Docenić należy zamieszczenie reprodukcji niektórych kart XV-wiecznego Prołogu oraz edycję zdjęć miejsc, gdzie przebywał męczennik supraski.

Antoni Mironowicz i Marcin Mironowicz wykorzystali nieliczne źródła ruskie, bułgarskie i greckie. Dzięki tym ostatnim uzyskano nieznane informacje dotyczące pobytu mnicha Antoniego na Świętej Górze Athos i w Salonikach. Opracowanie obu historyków stało się nie tylko ważnym wydarzeniem naukowym, ale otworzyło drogę do odrodzenia się kultu w monasterze supraskim. Dzięki monografii Świętego kult św. Antoniego Supraskiego zostanie rozpowszechniony w Grecji i Polsce. Jestem przekonana, że książka Św. Antoni Supraski zyska szerokie grono czytelników wśród historyków, teologów i badaczy dziejów Kościoła. 